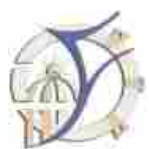

Fayoum University
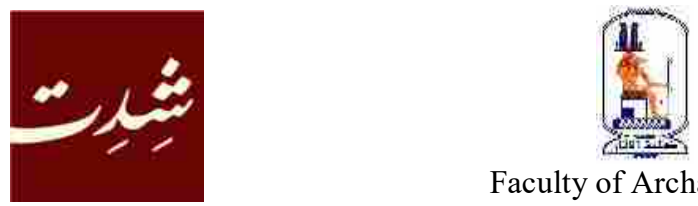

Faculty of Archaeology

\title{
THE INDEPENDENCY ACTIVITIES OF AHMED PAŞA AL-KRCHĪ AND THEIR REFLECTIONS ON THE OTTOMAN COINS IN EGYPT (929 A.H./1524 A.D.)
}

\author{
Ahmed M. YOUSEF \\ Faculty of Archaeology, Cairo University, Egypt \\ E-mail: amyousef1980@yahoo.com
}

\begin{abstract}
At the beginning of the reign of Sultan Sulaymân I ibn Selîm I in Egypt and the Levant, the Ottoman Empire faced many tribulations and independence movements which aimed to restore the power of the Mamluk State and show noncompliance to the Sultan's orders. However, these movements were toughly faced, thus could not stand in front of the Ottoman Empire. From this point, coins played an important role in studying separatism through studying revolutionaries' coins. Thus coins have been important documents and records preserving the history of revolutions throughout the different ages. One of the most important revolutionary movements was the one by Khaīn Paşa, the Egyptian governor during the era of Sultan Sulaymân who declared the rebellion against the Sultan's power, underestimated the Sultan by declaring himself the Sultan of Egypt, and struck coins under his name. But the Ottomans faced this movement forcefully until it was eliminated and Khaīn Ahmed Paşa was executed. Among the most important results were the successive monetary versions of gold and silver coins during the reign of Sultan Sulaymân, beside the emission of law which specified the transactions of the Egypt mint 'darbkhāne' or 'dār al-darb', and its minters 'darrābun'.
\end{abstract}

\section{Keywords}

dinar - Zer - maḥbūb - mint

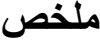

بلقي البحث الضوء على حركة أحمد باثنا أحد مماليك السلطّان سليم الاول الذي استمر في خدمة السلطان سليمان الندان

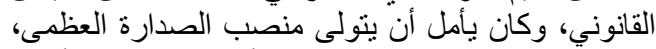
ولكن لم يجبه السلطان سليمان الأول بن سليم الألي الأول.

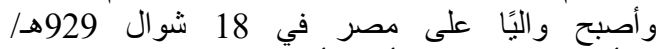
19أغسطس 1523م. أعلن أحمد بانشا العصيان واستبد

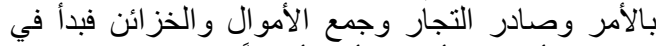

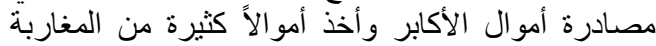

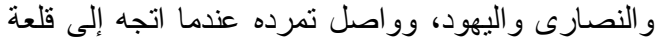

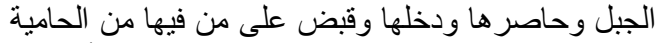

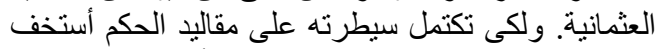
بالسلطان سليمان القانوني حديث العهد وأعلن نفسه سلطانًا

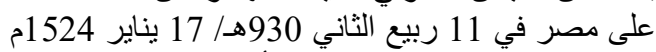

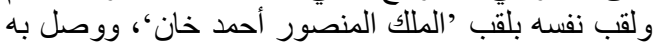
الآمر إلى تغيير علم الدولة العثمانية إلى علم خاص بلد بدولته

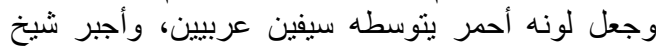

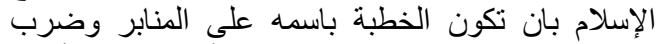
السكة من الدنانير و الدرا اهم باسمه لمدة أسبو عين في أو أو ائل

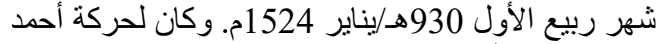

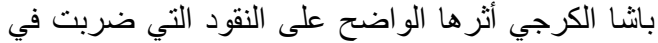

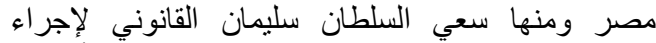
تعديلات إدارية على نظام الحكم بمصر خشية قيام العيام أعمال

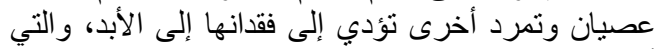

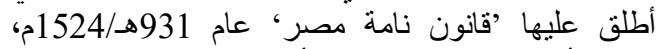
والذى أهتم بالنظر في كل الأمور المنعلقة بسك النقود الذهبية و الفضية ودار ألضرب ولالفر الصرر افين. الكلمات الالة الة الة الدينار - الزر - محبوب - دار الضرب 


\section{Introduction}

At the beginning of the reign of Sultan Sulaymân I ibn Selîm I in Egypt and the Levant, the Ottoman Empire faced many tribulations and independence movements which aimed to restore the power of the Mamluk State and show noncompliance to the Sultan's orders. However, these movements were toughly faced, thus could not stand in front of the Ottoman Empire. From this point, coins played an important role in studying separatism through studying revolutionaries' coins. Thus coins have been important documents and records preserving the history of revolutions throughout the different ages.

One of the most important revolutionary movements was the one by Khaīn Paşa, the Egyptian governor during the era of Sultan Suleiman who declared the rebellion against the Sultan's power, underestimated the Sultan by declaring himself the Sultan of Egypt and struck coins under his name. But the Ottomans faced this movement forcefully until it was eliminated and Khaīn Ahmed Paşa was executed.

One of its most important results was the successive monetary versions of gold and silver coins during the reign of Sultan Sulaymân I, beside the emission of law which specified the transactions of the mint in Egypt and its minters.

Khaīn Ahmed Paşa was one of the Mamluks for Sultan Selîm I, then he continued serving Sultan Sulaymân I ibn Selîm I, as he aimed for the great land after the great leader Mohamed Paşa Sādqi retired for his old age. ${ }^{1}$ Thus, Ahmed Paşa applied for this position, but Sultan Sulaymân I employed İbrahim Paşa instead of him, despite the supremacy of Ahmed Paşa and his exceptional personality.

İbrahim Paşa pushed Ahmed Paşa away from his great position by giving him the management of Egypt as he became the governor of Egypt on 18 Shāwal 929 A.H./ 19 August 1523 A.D. After that, he tried to kill Ahmed Paşa by sending letters to the princes in Egypt asking them to cut Ahmed's Paşa throat and send him his head. In return, he will choose one of them to take the leadership of Egypt. But Ahmed Paşa revealed the conspiracy and saw the letters, and cleverly got rid.

Then, Ahmed Paşa started to protect himself and killed some of Sultan Sulaymân's Mamluks, controlled the trader's role and took possession of the cabinet money. He also asked Ghanem Al-Hmzaui to present 150,000 Dinars and the Senate to pay 100,000 Dinars, and took more coins from the Al-mghrīb. Christians and Jewish continued his rebellion when he gathered some of the Arab brats and headed to the citadel and besieged it for 20 days, then arrested some of the Ottoman soldiers. ${ }^{2}$

In order to have full control over the reign of Sultan Sulaymân I, he underestimated him by trying to be independent from the Ottoman reign, and regain the power of the Burji Mamluk State. He declared himself the Sultan of Egypt on 11 Rabi' II 930 A.H./17 January 1524 A.D., and titled himself al-Malīk al-Manșūr Ahmed $\mathrm{Khan}^{3}$ (the victorious king Ahmed

\footnotetext{
${ }^{1}$ Ibn Abdel Moaty, Akhbar al-ūawl fìmn tșrffì mișr arbab al-dawl, p. 135.

${ }^{2}$ Al-Bakri, Al-rawḍa; Al-m'naws a;fì akhbar Miṣr Al-mhrūsa, p. 82; Al-Malwani, Tühaft al-'ḥbab bmn mlk Mișr mn al-mulūk aw al-nūab, p. 109; Al-Ghazy, Al-kawkib al-sa'ra; ba' 'ayn al-m' Al-'Ashra, pp. 159; AlNahrawali, Al-brq al-aymanī, p. 37; Ibn Abdel Moaty, Akhbar al-ūawl fìmn tșrffī mișr arbab al-dawl, p. 135.

${ }^{3}$ Al-Ghazy, Al-kawkib al-sa'ra; ba' 'ayn al-m'al- 'ahrra, pp.159; Al-Bakri, Al-rawda Al-m'naws a; fí akhbar Mișr, p.82; Mousa, Sfhat mțaya mn Tarīkh Mișr al- 'Uthmāniya, pp. 34-35; Sayed, Mișr fì al- 'așr al- 'Uthmāni fí al-qrn 16 al-Mīlādī, pp.118:119.
}

- 129 - The Independency Activities of Ahmed Pasha Al-Karji ... on the Ottoman Coins ... 
Khan), al- 'Adl (the fair), and 'malik al-umarā naīb al-dyār al-mașriyah'. ${ }^{5} \mathrm{He}$ also changed the flag of the Ottoman Empire and introduced a new flag for his new state: red colored with two Arabian swords. ${ }^{6}$

Ahmed Paşa started to instill his policy and ordered that the Imams to make their sermons in his name in mosques. He also struck dinars and dirham with his name for two weeks at the beginning of Rabi'1 in 930 A.H./ January 1524 A.D. ${ }^{7}$

Along with the challenges faced by Ahmed Paşa Al-Krchī, he did not find any support. At the international level, the Levant was not satisfied and armed the Damascus Citadel to face his movement, ${ }^{8}$ while the Mecca royals saw that he was aiming at destroying the Egyptian Kingdom. ${ }^{9}$ The Ottoman State did not stand still, but began to collide against him and agreed with Cairo princes, on top of whom was Chānim Al-ḥmzaaway, to get rid of him upon the command of Sultan Sulaymân I. He was attacked beside Citadel in Cairo the on 17 Rabi' 1930 A.H./23 January 1524, but he ran away until he reached the Arab Sheikh 'Abd al-Dāīm bin Bakr. ${ }^{10}$

General upraise was announced to fight Ahmed Paşa, in which the Roman, the Levant, the Moroccan, and the al-'ūam tribes rose, called the judges, went to the citadel, and Ahmed Paşa's actions were revealed. The announcer called for attack against him, and simultaneously a thousand soldiers came from Istanbul to Alexandria, sent by Sultan Sulaymân I ibn Selîm I. Everyone united against him, and he was captured and slaughtered. His head was hanged on Zuweila Gate on 29 Rabi' 1930 A.H./ 5 March 1524 A.D, then it was sent to Sultan Sulaymân on 3 Jūmada 1930 A.H./ 8 March 1524 A.D. ${ }^{11}$

Among the factors that aided Ahmed Paşa in his revolt was Egypt's location- being far from the Ottoman State, and having great material resources and vast lands. All these factors led him to announce his revolt and rebellion against the Ottoman State. This is in addition to the existence of the Mamluk who were against the Ottoman reign, mistakenly believing that such privileges will be enough to achieve victory and independence from the Ottoman State. ${ }^{12}$

\section{Ahmed Paşa al-Krchī Movement and its Reflection on Coins in Egypt}

The movement of Ahmed Paşa al-Krchī had its apparent impact on coins struck in Egypt, as Sultan Sulaymân I strove to make administrative amendments in the ruling system in Egypt in fear of any revolt or rebellion leading to its total loss. He called it Egypt's Development Law in 931 A.H/ 1524 A.D., ${ }^{13}$ focusing on everything concerning remint gold and silver

\footnotetext{
${ }^{4}$ Al-Hemsy, Hawdth al-zman aw awfiat al-shaykh aw al-' 'qran, p. 572.

${ }^{5}$ Al-Maleky, Nīl al-munay bidhīl blügh al-quray, pp. 349-350.

${ }^{6}$ Sayed, Mișr fì al- 'așr al- 'Uthmāni fì al-qrn 16 al-Mīlādī, pp. 118-119.

${ }^{7}$ Al-Nahrawali, Al-brq al-aymanī, p. 37; Al-Maleky, Nīl al-munay, p. 350; Ibn Abdel Moaty, Akhbar al-ūawl fìmn tșrf f ̄ mișr arbab al-dawl, p. 135; Al-Ghazy, Al-kawkib al-sa'ra; ba' 'ayn al-m 'al- 'ahrra, p. 159; AlBakri, Al-rawda; Al-m 'naws a; fì akhbar Mișr, p. 82; Ahmed (Fouad), Qanūn nama Mișr, p. 4; Sayed, Mișr fì al- 'așr al- 'Uthmāni fì al-qrn 16 al-Mīlādī, p.120; Al-Șāwī, Al-Nuqud al-Mutadāwala, p. 26.

${ }^{8}$ Al-Hemsy, Hawdth al-zman aw awfiat al-shaykh aw al-' 'qran, p. 572.

${ }^{9}$ Al-Maleky, Nĩl al-munay, p. 350.

${ }^{10}$ Al-Nahrawali, al-brq al-aymanī, p.37. Al-Maleky, nīl al-munay, p.350. Ibn Abdel Moaty, Akhbar al-ūawlf ìmn tșrff ̄̄ miṣr arbab al-dawl, p.135. Al-Ghazy, al-kawkib al-sa'ra; ba' 'ayn al-m' al- 'ahrra, p. 159. Al-Bakri, Al-rawḍa Al-m 'naws a; fì akhbar Miṣr, p. 82.

${ }^{11}$ Al-Ghazy, Al-kawkib al-sa'ra ba' 'ayn al-m 'al- 'ahrra, p. 159.

${ }_{12}$ Abdel Kareem, The Arabs and the Ottomans, p. 86

${ }^{13}$ Daniel, Jdhür Miṣr al-hìtha, p. 46.
} 
coins, the mints, and accountants, as follows:

\section{1- Controlling the Mint}

On top of the precautionary developments after Ahmed Paşa al-Krchī was controlling the mint through Sultan Sulaymân I ibn Selîm I who solely had the right to appoint the mint secretary, and the Head of Princes of Egypt may fire him if he sensed any shortage, carelessness or treason in his work. The case is then forwarded to the Sultan, but the latter does not have the right to appoint another; I ask for a trusted person to be appointed in his place. $^{14}$

Since that decision, controlling mints has become one of the most important occupations given high significance on behalf of the Ottoman State in all the states under its rule through one of its officers, workers, or a specific representative sent from the royal family. ${ }^{15}$ The reason behind this might be the importance of such an organization at the political and economic levels for the Ottoman State, as it has been traditionally administered by the state. $^{16}$

As for the source of metal for the mint, Sultan Sulaymân I issued a decree banning and forbidding the accountants transfer through the cities to buy gold from anyone to preserve it, then resell it to the officer Thus, he who does not find it with anyone else and has no choice but to resort to the accountants. Such accountants in turn sell it with the value they estimate, and their punishment is withdrawing their money. ${ }^{17}$

The importance of this decree lies in banning the accountants' monopolization of gold import to the mint, leading to the stabilization of the gold price used to struck the gold coins without any increase.

\section{2- Sultan Sulaymân I Policy in remint Gold Coins}

The gold Ottoman coins are considered one of the main pillars of the financial system in the Ottoman State, and since their issuance, they strove to have a unified financial form in resemblance to the gold coins terms of weight and standard. ${ }^{18}$ The gold Ottoman coins were different from other states' coins by the distinguished type of inscription of the dates recorded on them. Such dates refer to the crowning of the Ottoman Sultan to the throne without registering the actual issuance date, ${ }^{19}$ through a decree by the Sultan to struck new coins. This process was known as the Renewed Struck, in which the old coins are banned and exchanged from the mint with the new coins. ${ }^{20}$

\footnotetext{
${ }^{14}$ Ahmed, Qanūn nama Mișr, p. 77.

${ }^{15}$ Samuel, Al-nqud wa Al-mawazayn, p. 257; Akmal, Al-dawlh al-'Uthmāniya, pp. 669-670.

${ }^{16}$ Shawkat, Al-Tarīkhal-malī, p. 79.

${ }^{17}$ Ahmed, Qanūn nama Mișr, p. 77.

${ }^{18}$ Shawkat, Al-Tarīkhal-malī, p. 240.

${ }^{19}$ Raafat, Al-tarīkh al-hjrī, p. 240

${ }^{20}$ Akmal, Al-dawlh al- 'Uthmāniya, pp. 666; Shawkat, Al-Tarīkhal-malī, p. 240.
}

- 131 - The Independency Activities of Ahmed Pasha Al-Karji ... on the Ottoman Coins ... 
Since Sultan Sulaymân I came to the throne, the Egyptian mint proceeded in issuing gold coins with the date of his crowning in 926 A.H/ 1520 A.D. ${ }^{21}$ Two coins belonging to this type are preserved in the Egyptian National Library and Archives, ${ }^{22}$ while Artuk published another one which belonged to this type as well. ${ }^{23}$ The inscriptions and decorations of this type were as follows (pls. nos.1-2):

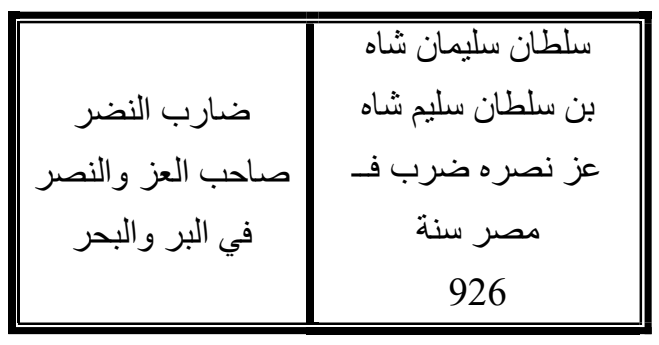

Four coins which belong to the same type are preserved in the British Museum, ${ }^{24}$ while William Qazan published another two coins belonging. ${ }^{25}$

Among the main goals that Ahmed Paşa strove to achieve was proving his legitimacy through striking coins with his name and changing the type of coins struck by Sultan Sulaymân I, having in mind that coins are one of the major powers of ruling. He is considered the first to cut the ckhain of Ottoman coins milled in Egypt. ${ }^{26}$ Sources agreed upon the coinage of a new Egyptian currency of dinars and dirham with Ahmed Paşa's name ${ }^{27}$, with the inscription of the statement Long Live Sultan Ahmed's Power. ${ }^{28}$

Among the main coins reform by Sultan Sulaymân I to control Ahmed Paşa al-Krchī’s coins are:

1- The confiscation of Ahmed Paşa al-Krchī's funds, as no coins of such unique numismatics have been found in the history of the Ottoman rule in Egypt. The reason behind this might be the short period of time Ahmed Paşa ruled, being known as the traitor. ${ }^{29}$ Views have differed, for some believed he ruled for six months, ${ }^{30}$ while others saw that he ruled for a year ${ }^{31}$. Egypt's new ruler Gūslcha Kasm Paşa collected all the coins issued by Ahmed Paşa as soon as he arrived to Egypt in 931 A.H /1524 A.D. ${ }^{32}$

2- Sultan Sulaymân I determined the coinage of the Sultan Coin (the Ottoman Dinar) from the gold imported from Tkrur countries, struck in the special standard mint based on the law followed in Constantinople, as each Sultan strikes with a standard of 18.5 carats of alloy or

\footnotetext{
${ }^{21}$ Lane, Catalogue of Oriental Coins, pp. 80-81.

${ }^{22}$ Record No. 3518, $2.5 \mathrm{~g} 19 \mathrm{~mm}$, record No. 3521, 3.4 g, $20 \mathrm{~mm}$.

${ }^{23}$ Artuk, Istanbul Arkeoloji, No. 153

${ }^{24}$ Lane, Catalogue of Oriental Coins, No. 202, 203, 204, 205, pp. 80 - 81.

${ }^{25}$ William, Collection of William Kazan, No. 753, 754, p.363.

${ }^{26}$ Al-Șāwī, Al-Nuqud al-Mutadāwala, p. 27.

${ }^{27}$ Al-Hemsy, Hawdth al-zman aw awfiat al-shaykh aw al-' 'qran, p.572; Al-Nahrawali, Al-brq al-aymanī, p. 38. Al-Maleky, Nīl al-munay, p.350; Ibn Abdel Moaty, Akhbar al-ūawl fìmn tșrff ì mișr arbab al-dawl, p. 135; AlGhazy, Al-kawkib al-sa'ra ba' 'ayn al-m' al- 'ahrra, p.159.

${ }^{28}$ Sayed, Miṣr fì al- 'aṣr al- 'Uthmāni fì al-qrn 16 al-Mīlād̄̄, p.120; Al-Șāwī, Al-Nuqud al-Mutadāwala, p. 27.

${ }^{29}$ Al-Șāwī, Al-Nuqud al-Mutadāwala, p. 27.

${ }^{30}$ Al-Malwani, Tühaft al- 'ḥbab bmn mlk Miṣr, p. 109.

${ }^{31}$ Al-Bakri, Al-rawḍa Al-m 'naws a fi akhbar Mișr, p. 82.

${ }^{32}$ Al-Ṣāwī, Al-Nuqud al-Mutadāwala, p. 27.
} 
golden pots and receives a fee of ten golden coins for each hundred mithqal. ${ }^{33}$ What made Sultan Sulaymân I do so was his attempt to fix the standard that was low at the beginning of his age when he sent a letter to Prince Khaīr Bīk to amend the exchange of gold and silver in 926 A.H/ 1520 A.D, ${ }^{34}$ along with connecting the standard of the gold coins struck in Egypt with those struck in Constantinople for the Ottoman State to preserve a fixed exchange rate of the coins struck in Egypt. ${ }^{35}$

3- Sultan Sulaymân I was keen on striking the gold coins in the same year when Ahmed Paşa al-Krchī's coins were banned in 930 A.H, and it was followed by searching museums, catalogues, and private collections. This led to the Egyptian mint did not issue any gold coins of Sultan Sulaymân I dated 927 A.H. and 928 A.H., in addition to 929 A.H. in which Ahmed Paşa al-Krchī was appointed to rule Egypt. Thus, it can be concluded that the coins struck since 930 A.H. represent the new coins issued after getting rid of Ahmed Paşa al-Krchī's coins with the aim of restoring confidence in the Ottoman gold coins after removing the statements inscribed by Ahmed Paşa of Long Live Sultan Ahmed's Power. ${ }^{36}$

\section{The New Coins Struck by Sultan Sulaymân I}

One of the most important results of Ahmed Paşa al-Krchī's revolution was the struck of new types of gold coins of Sultan Sulaymân I with the inscription of the struck date instead of the date of crowning the Sultan to the throne since 930 A.H. until 933 A.H. This is considered a very important alteration, in giving up the struck of the date of crowning the Sultan to the throne on coins for the aim of getting rid of Ahmed Paşa al-Krchī's coins, as follows.

\section{1- The First Type of Gold Coins Struck in Egypt in 930 A.H.}

This type can be witnessed in two coins preserved in the Egyptian National Library and Archives, ${ }^{37}$ in which the inscriptions and decorations of this type were as follows (pls.nos.3/4):

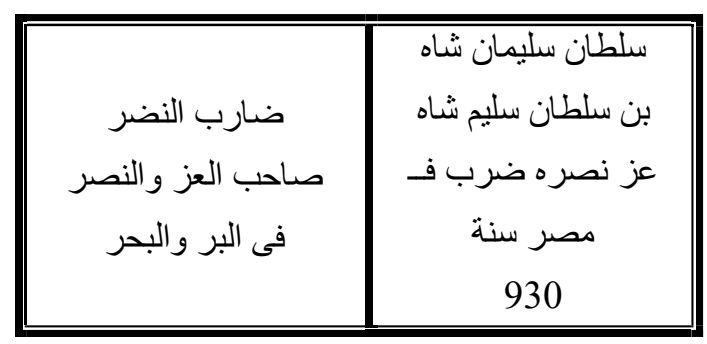

This type was distinguished in terms of the general form as the inscriptions on the obverse and reverse were in horizontal lines inside a prominent lined circle. ${ }^{38}$ On the observe, the names of Sultan Suleiman and his father Sultan Selîm were inscribed given the title Shah, along with the actual date of striking in 930 A.H, in addition to the location of striking in

\footnotetext{
33 Ahmed, Qanūn nama Miṣr, p.92; Shawkat, al-Tarīkhal-malī, pp. 80-81; Shaw, The Financial and Administrative, p. 367.

${ }^{34}$ Ibn Iyas, Bda' 'al-zhur, p. 354

${ }^{35}$ Samuel, Al-nqud wa Al-mawazayn, pp. 161-162.

${ }^{36}$ Sayed, Miṣr fì al- 'aṣr al- 'Uthmāni fì al-qrn 16 al-Mīlādī, pp.121; Al-Ṣāwī, al-Nuqud al-Mutadāwala, p.27.

${ }^{37}$ Record No. 3524, $3.2 \mathrm{~g} 19.5 \mathrm{~mm}$, record No. 3525, 3.5g , $20 \mathrm{~mm}$.

${ }^{38}$ Raafat, Al-Nuqud al-'Islāmiyya fì Miṣr, p. 240.
}

- 133 - The Independency Activities of Ahmed Pasha Al-Karji ... on the Ottoman Coins ... 
Egypt that was usually preceded by the preposition (in). ${ }^{39}$ On the reverse, the old Ottoman inscription was added stating the succulent minter the glorious and victorious in the land and seas. William also published three coins belonging to this type. ${ }^{40}$

\section{2- The Second Type of Gold Coins Struck in Egypt in 931 A.H.}

This type can be witnessed in a coin preserved among a private collection in the United Arab Emirates ${ }^{41}$ in which the inscriptions and decorations of this type were as follows (pl. no.5)

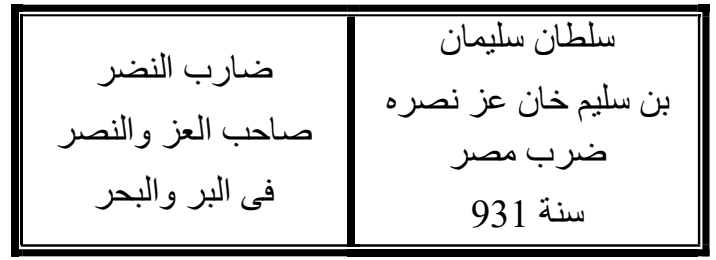

\section{3- The Third Type of Gold Coins Struck in Egypt in 932 A.H.}

This type can be witnessed in a coin preserved in the Egyptian National Library and Archives published for the first time ${ }^{42}$, and Artuk published another coin belonging to the same type ${ }^{43}$, in which the inscriptions and decorations of this type were as follows (pl. no.6)

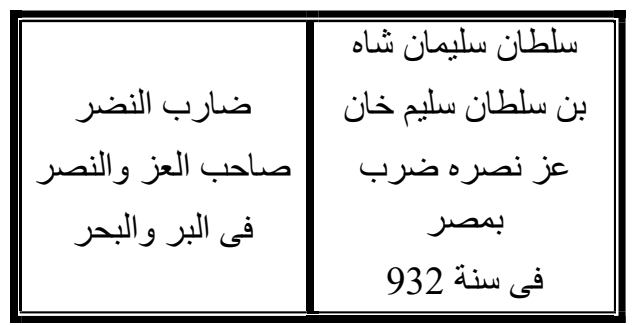

\section{4- The Fourth Type of Gold Coins Struck in Egypt in 933 A.H.}

This type can be witnessed in a coin preserved among a private collection ${ }^{44}$ in which the inscriptions and decorations of this type were as follows (pl. no.7)

\begin{tabular}{|c|c|}
\hline صاحب العز و النصر النضر & بن سلطان سليمان شاه سليم شاه \\
\hline
\end{tabular}

\section{3- Reforming Silver Coins}

Sultan Sulaymân I started reforming silver coinage by the beginning of his rule in 926 A.H./1520 A.D., due to the major decrease in weight and standard. ${ }^{45}$ Sulaymân I determined that coinage would be minted in Egypt mint from Ottoman alloy or from silver topical alloy in which each hundred dirham of it equals eighty four dirham of pure silver and sixteen fake silver, deducting what the fire burns, and for each hundred dirham 250 para are minted. ${ }^{46}$

\footnotetext{
${ }^{39}$ Al-Ṣāwī, Al-Nuqud al-Mutadāwala, p.25.

${ }^{40}$ The Coinage of Islam, Collection of William Kazan, No. 755, 756, 757, p.363

${ }^{41}$ United Arab Emirates, Private Collection, $2.9 \mathrm{~g}, 20 \mathrm{~mm}$.

${ }^{42}$ Record No. 3526, 2.6g, $19.5 \mathrm{~mm}$.

${ }^{43}$ Artuk, Istanbul Arkeoloji, No. 155.

${ }^{44}$ Private Collection, $3.3 \mathrm{~g}, 20 \mathrm{~mm}$

${ }^{45}$ Ibn Iyas, bda' 'al-zhur, p. 354.

${ }^{46}$ Ahmed, Qanūn nama; Mișr, p. 92.
} 
This procedure depends on the Ottoman State's responsibility to provide the silver raw material from Anatalia and Balkan mines to be sent to Egypt in order for Egypt mint to struck Aqchat $^{47}$. The single bāra contained 1.075 gm. of pure silver, which is almost $50 \%$ more than that what the contemporary aqcha; contained. ${ }^{48}$
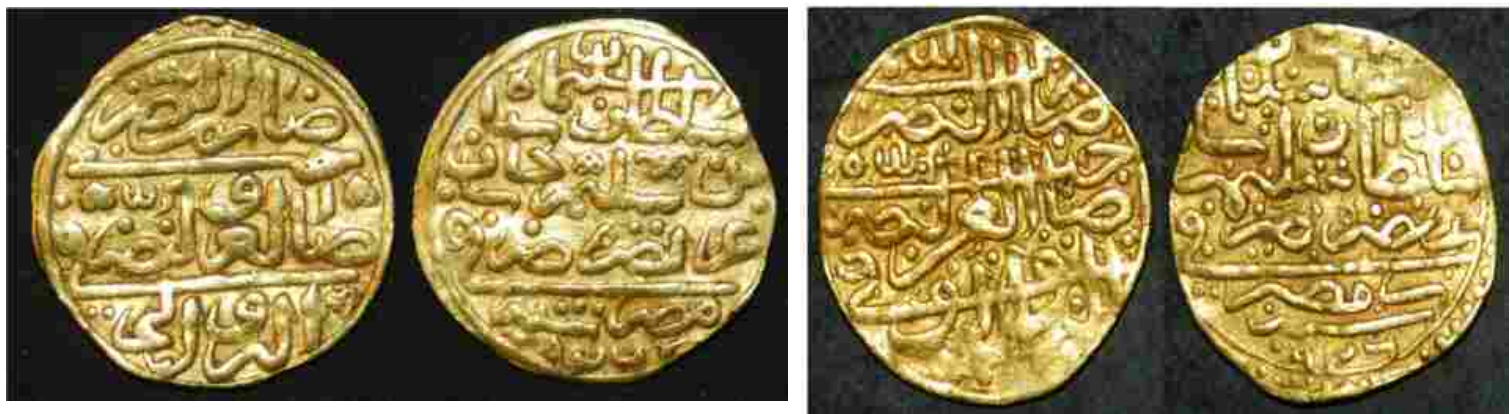

Pl. no. 1: Dinar struck in Egypt in 926 A.H. with the name of Sultan Sulaymân I, preserved in Egyptian National Library and Archives No. 3518, $2.5 \mathrm{~g} 19 \mathrm{~mm}$.

Pl. no. 2: Dinar struck in Egypt in 926 A.H. with the name of Sultan Sulaymân I, preserved in Egyptian National Library and Archives No. 3521, $3.4 \mathrm{~g}, 20 \mathrm{~mm}$
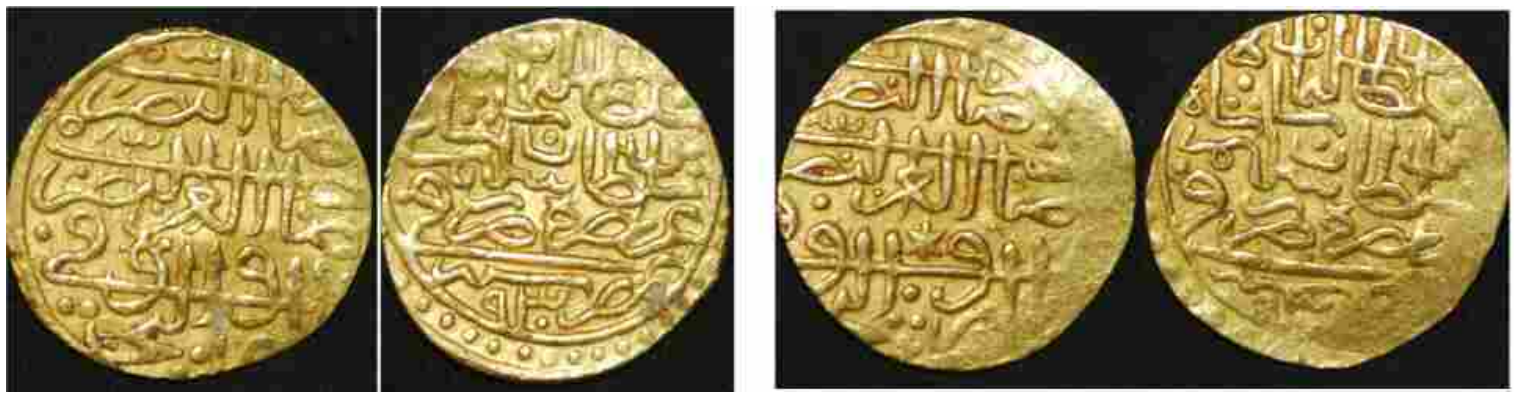

Pl. no. 3: Dinar struck in Egypt in 930 A.H. with the name of Sultan Sulaymân I, preserved in Egyptian National Library and Archives No. 3524, 3.2 g $19.5 \mathrm{~mm}$.
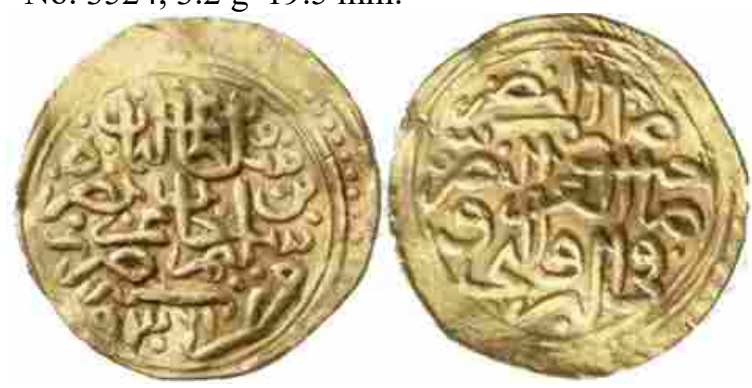

Pl. no. 4: Dinar struck in Egypt in 930 A.H. with the name of Sultan Sulaymân I, preserved in Egyptian National Library and Archives No. $3525,3.5 \mathrm{~g}, 20 \mathrm{~mm}$.

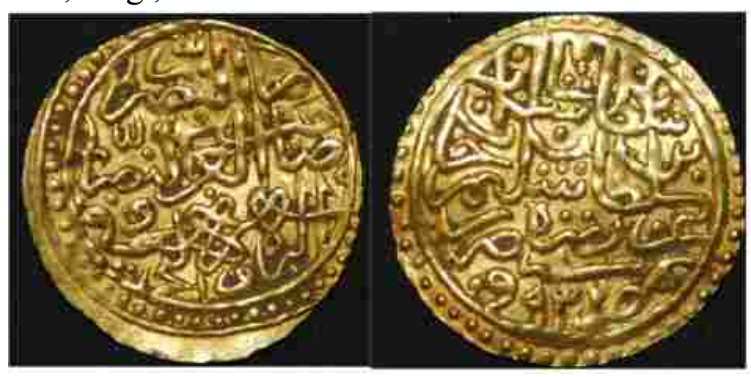

Pl. no. 5: Dinar struck in Egypt in 931 A.H. with the name of Sultan Sulaymân I, preserved in United Arab Emirates (private collection), 2.9 g, $20 \mathrm{~mm}$.

Pl. no. 6: Dinar struck in Egypt in 932 A.H. with the name of Sultan Sulaymân I, preserved in Egyptian National Library and Archives No. $3526,2.6 \mathrm{~g}, 19.5 \mathrm{~mm}$.

\footnotetext{
${ }^{47}$ Shawkat, Al-Tarīkhal-malī, p. 82-83.

${ }^{48}$ Shawkat, Al-Tarīkhal-malī, p. 184.
}

- 135 - The Independency Activities of Ahmed Pasha Al-Karji ... on the Ottoman Coins ... 


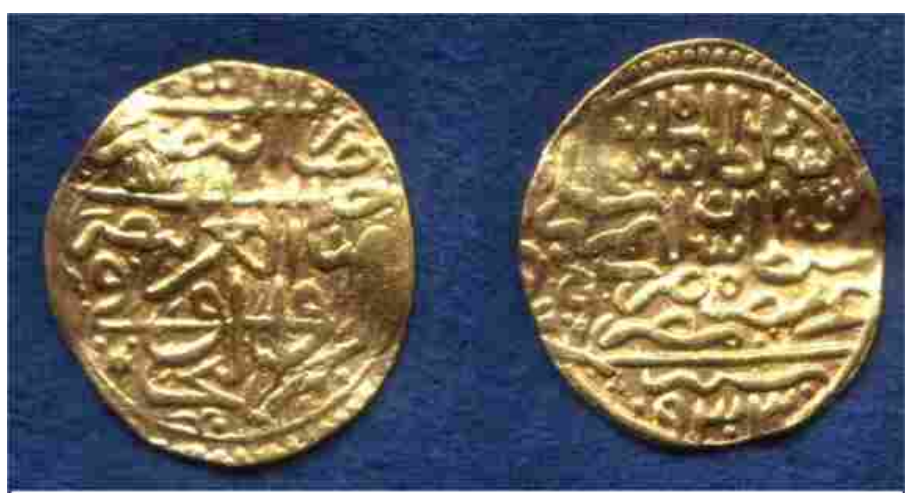

4P1. no. 7: Dinar struck in Egypt in 933 A.H. with the name of Sultan Sulaymân I, preserved in United Arab Emirates (private collection) $3.3 \mathrm{~g}, 20 \mathrm{~mm}$.

\section{CONCLUSION}

The Paper confirmed that Sultan Sulaymân I ibn Selîm I solely had the right to appoint the mint secretary. It also established that Sultan Sulaymân I Issued a decree banning and forbidding the accountants transfer through the cities to buy gold from anyone to preserve it. The Study revealed that Sultan Sulaymân I was keen on striking gold coins in the same year when Ahmed Paşa Al-Krchī's coins were banned in 930 A.H. The Research shed light on new types of gold coins of Sultan Sulaymân I which emerged with the inscription of the date of issuance form 930 A.H. until 933 A.H. 


\section{REFERENCES}

Abdel Kareem (Rafeq), Ala'rab wa al-o thman 1516- 1916 (The Arabs and the Ottomans 15161916), $1^{\text {st }}$ ed, Al-Alaf Baa Publishing, Damascus, 1974.

Ahmed (Fouad), Qanūn nama Miṣr (Egypt's Development Law), The Anglo- Egyptian Library, Cairo, 1986.

Akmal al-Din (Ihsan), Al-dawlh al-'Uthmāniya Tarīkh wa Hḍara; (Umayyad State: History and Civilization), transferred by Saleh Se'dawy, vol.1, IRCICA, Istanbul, 1999.

Al-Bakri, (Mohamed bin Abu al-Sorour al-Sadiqi), Al-rawda; Al-m'naws a fì akhbar Mișr Al$m h r u \bar{s} a$, Abdel Razeq Abdel Razeq (ed.), $1^{\text {st }}$ ed, Religious Culture Library, Cairo, 1997.

Al-Ghazy, (Najm al-Din Mohamed bin Mohamed), Al-kawkib Al-sa'ra ba' ayn al-m' Al- 'Ashra;, footnotes by Khalil al-Mansour, vol.(1), $1^{\text {st }}$ ed, Academic Books Publishing, Beirut, 1997.

Al-Hemsy, (Ahmed bin Mohamed bin Omar al-Ansary), Hawdth Al-zman aw Awfiat Al-shaykh aw Al-' qran, Abdel Aziz Fayad Harfoush (ed.), al-Nafaes Publishing, Beirut, 2001.

Al-Ishaqy, (Mohamed bin Abdel Moaty bin Ahmed bin Abdel Moghny), Akhbar Al-ūawl fì mn tșrffì mișr arbab Al-dawl, Al-Amara Al-Sharqia Publishing, Egypt, 1315 A.H.

Al-Makki, (Qotb al-Din Mohamed bin Ahmed al-Nahrawali), Al-brq Al-aymañ̄ fì al-fth al- 'Uthmāni, Hamad al-Jasser (ed.), $1^{\text {st }}$ ed, al-Yamama Publishing, Riyyad, 1967.

Al-Maleky, (Jar Allah bin al-Ezz bin Fahd), Nìl Al-munay Bidhīl Blūgh Al-quray, Mohamed al-Habib al-Haila (ed.), $1^{\text {st }}$ ed, vol.(1), Quran Institution for Islamic Heritage, Mecca, 2000.

Al-Malwani, (Youssef bin Mohamed), Tūhaft Al-'hbab bmn mlk Miṣr mn Al-mulūk aw Al-nūab, Mohamed al-Sheshtawy (ed.), $1^{\text {st }}$ ed, Arab Horizons Publishing, Cairo, 1999.

Al-Qarmani, (Ahmed bin Youssef), Akhbār Al-dawl aw Äthār Al-awl, Ahmed Heteit and Fahmy Saad (ed.), vol.(3), $1^{\text {st }}$ ed, Books World, Beirut, Lebanon, 1992.

Artuk (Ībrahim), Cevriye, Istanbul Arkeoloji Müzeleri Teshrdeki Islami Sikkeler Katalogu, cilt. II, Istanbul, 1974.

Daniel (Chrisilious), Jdhür Miṣr Al-hdītha (The Roots of Modern Egypt), translated by Abdel Wahab Bakr, Nahdat al-Sharq Library, Cairo, 1985.

Lane Poole (Stanley), Catalogue of Oriental Coins in the British Museum, Vol. (8), London, 1883.

Ibn Iyas, (Mohamed bin Ahmed Al-Hanafy), Bda' 'al-zhur fi Awqa' 'Al-dhur, Mohamed Mostafa (ed.), $3^{\text {rd }}$ ed, vol.5, the Public Egyptian Organization for Books, Cairo, 1984.

Mousa (Nasr), Șfhat Mțaya; mn Tarīkh Mișr al- 'Uthmāniya (Hidden Pages from the Ottoman History of Egypt), the Public Egyptian Association, Cairo, (1988).

Raafat (Al Nabarawy), Al-Nuqud al-'Islāmiyya fì Mișr 'așr Dawlh Al-Mamlūk (Islamic Money in Egypt in the Mamluk era), $1^{\text {st }}$ ed, Center of Arab Civilization, Cairo, 1996.

Raafat (Al Nabarawy), "Al-tarīkh Al-hjrī 'ala Al-Nuqud Al-'Islāmiyya," (in Arabic= The Hijri Date on Islamic Coins), Al- 'oșur Journal, Vol. (IV), Part II, Dar Al Marikh Publishing, London, 1989.

Samuel (Bernard), Al-nqud wa Al-mawazayn (in Arabic= Scales and Coins), translated by Zoheir Al Shayeb, vol. 6, Madbouly Library, Cairo, (2002).

Sayed (Mohamed), Mișr fì Al- 'așr Al- 'Uthmāni fì al-qrn 16 Al-Mīlādī (Egypt in the Ottoman Era in the Sixteenth Century), Madbouly Library, Cairo, 2003.

Shawkat (Bamouk), Al-Tarīkh Al-malī ll Daūla Al- 'Uthmāniya ((A Monetary History of the Ottoman Empire), $1^{\text {st }}$ ed, Islamic Madar Publishing, Lebanon, 2005.

Stanford J. (Shaw), The Financial and Administrative Organization and Development of Ottoman Egypt 1517-1798, Princeton, N.J., Princeton University Press, 1962.

The Coinage of Islam: Collection of William Kazan, Beirut, Lebanon: William Kazan, Bank of Beirut 1983.

- 137 - The Independency Activities of Ahmed Pasha Al-Karji ... on the Ottoman Coins ... 